
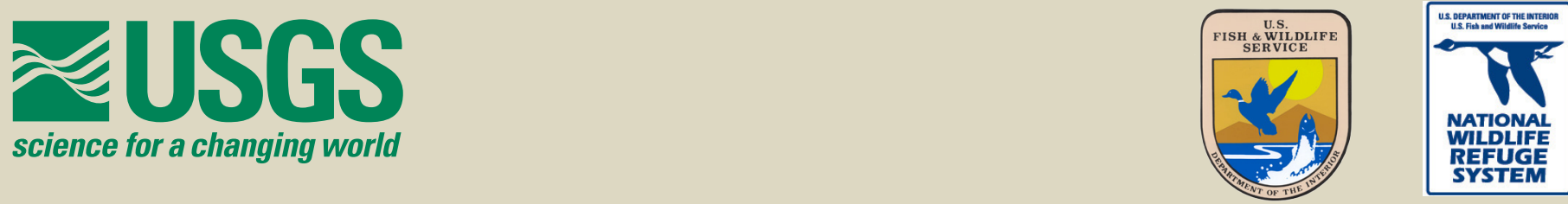

\title{
National Wildlife Refuge Visitor Survey Results: 2010/2011
}

By Natalie R. Sexton, Alia M. Dietsch, Andrew W. Don Carlos, Holly M. Miller, Lynne Koontz and Adam N. Solomon

Refuges make me aware that I am a part of the American experience and not just an observer. Nowhere else do I feel such a deep sense of connection with the land, the plants, and the wildlife. Visiting a refuge is truly a spiritual experience.-Survey comment from a national wildlife refuge visitor.

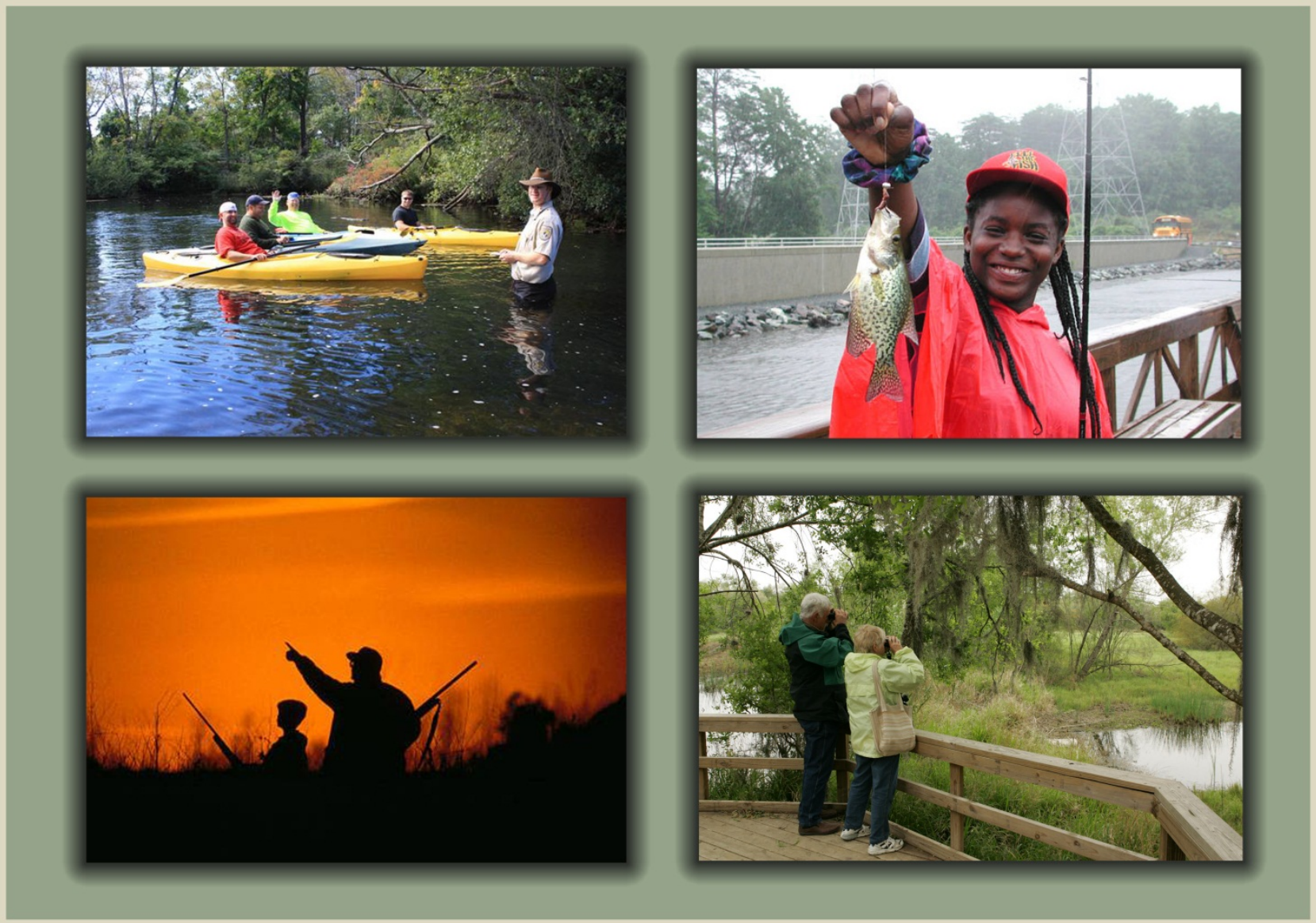

Photos courtesy of U.S. Fish and Wildlife Service. 


\section{Contents}

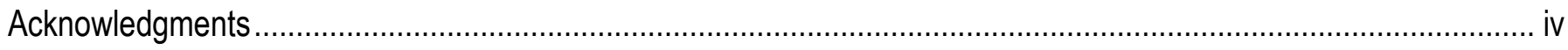

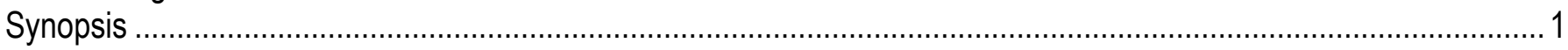

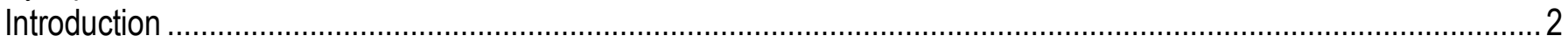

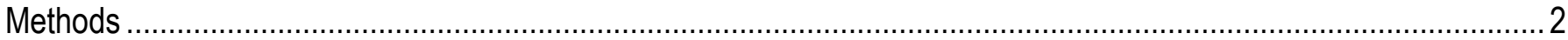

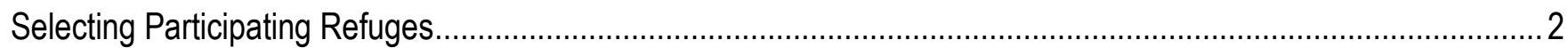

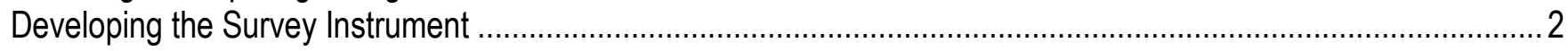

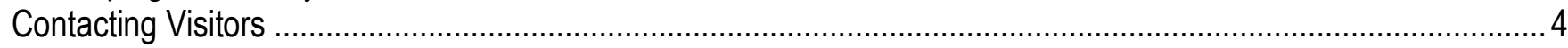

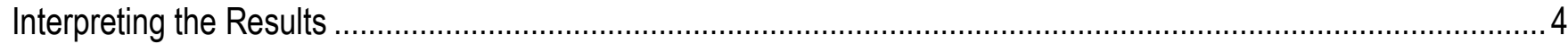

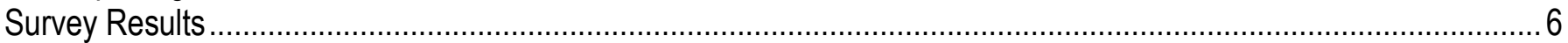

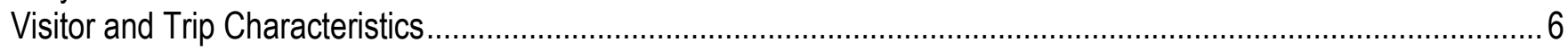

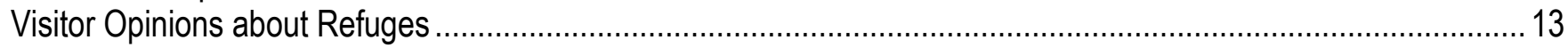

Visitor Opinions about National Wildlife Refuge System Topics..................................................................... 18

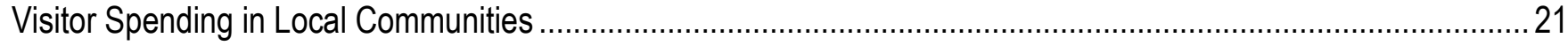

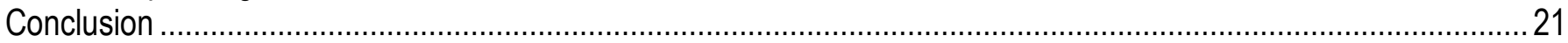

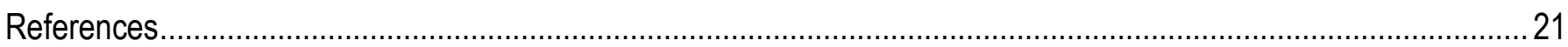




\section{Figures}

1. How visitors first learned or heard about refuges............................................................................... 7

2. Median distance travelled by visitors to each participating national wildlife refuge .......................................... 8

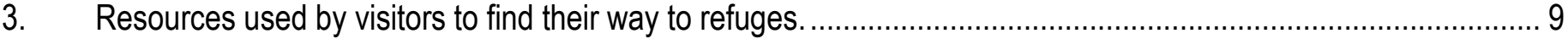

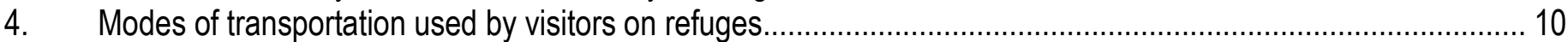

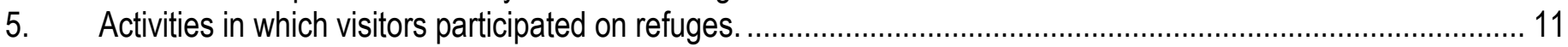

6. The primary activity in which visitors participated during their visits. ............................................................ 11

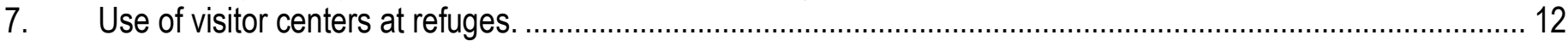

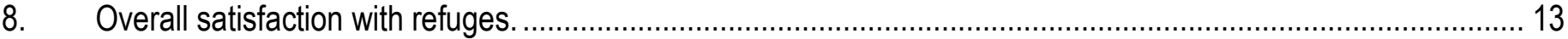

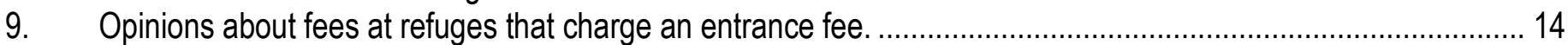

10. Importance-satisfaction ratings of services and facilities provided at refuges................................................. 15

11. Importance-satisfaction ratings of recreational opportunities provided at refuges. ............................................ 16

12. Importance-satisfaction ratings of transportation-related features at refuges. ................................................. 17

13. Visitors' likelihood of using alternative transportation options at refuges in the future. ...................................... 18

14. Visitors' personal involvement with climate change related to fish, wildlife and their habitats............................ 19

15. Visitors' beliefs about the effects of climate change on fish, wildlife and their habitats........................................ 20

\section{Tables}

1. Participating refuges in the $2010 / 2011$ national wildlife refuge visitor survey. ................................................. 3

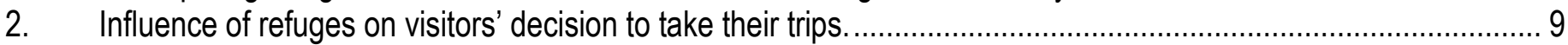

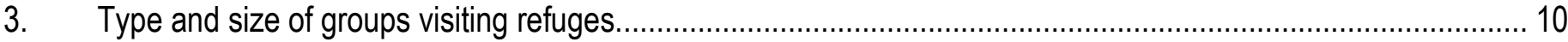

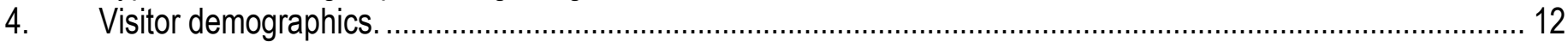




\section{Acknowledgments}

This study was commissioned by the U.S. Fish and Wildlife Service (Service) Division of Visitor Services and Communications Headquarters Office, Arlington, Virginia. The study design and survey instrument were developed collaboratively with representatives from the Service and researchers from the Policy Analysis and Science Assistance Branch, U.S. Geological Survey. For their support and input to the study, we would like to thank Kevin Kilcullen, Chief of Visitor Services; Steve Suder, National Transportation Coordinator; Regional Office Visitor Services Chiefs and Transportation Coordinators; and the staff and volunteers at all participating refuges who assisted with the implementation of this surveying effort. The success of this effort is largely a result of their dedication to the refuge and its resources as well as to the people who come to explore these unique lands. We also would like to thank the following PASA team members for their hard work throughout the surveying effort, which has included (among many things) the arduous tasks of stuffing more than 20,000 envelopes, managing multiple databases, and preparing numerous reports: Shannon Conk, Halle Musfeldt, Phadrea Ponds, Gale Rastall, Margaret Swann, Emily Walenza, and Katie Walters. 


\section{Synopsis}

The national wildlife refuge visitor survey was conducted on 53 refuges across the National Wildlife Refuge System (Refuge System) to better understand visitor needs and experiences and to design programs and facilities that respond to those needs. A total of 14,832 visitors agreed to participate in the survey between July 2010 and November 2011. In all, 10,233 visitors completed the survey for a 71\% response rate. This report provides a summary of visitor and trip characteristics; visitor opinions about refuges and their offerings; and visitor opinions about alternative transportation and climate change.

\section{Visitor and Trip Characteristics}

- More than half of visitors had been to multiple national wildlife refuges in the past year and had been multiple times to the refuge where they were contacted to participate in the survey.

- Visitors first learned or heard about refuges from friends and relatives, signs on the highway, people in the local community, and printed information from the refuge.

- More than half of visitors were nonlocal, living farther than 50 miles from the refuge they visited. Nonlocal visitors stayed in the local community for an average of 4 days and the refuge was the primary destination of the trip for many of them. The refuge was also the primary destination of the trip for the majority of local visitors.

- Visitors relied on previous knowledge and signs on highways to find their way to refuges. Once on a refuge, visitors stayed an average of 5 hours during an 8-hour day.

- The top three activities in which visitors participated during the 12-month period before they were contacted were wildlife observation, bird watching, and photography. During visitors' most recent trip to the refuge, the three primary activities were wildlife observation, bird watching, and fishing.

- Visitors were predominantly U.S. citizens and were a mix of 58\% male (with an average age of 54 years) and $42 \%$ female (with an average age of 52 years). Visitors, on average, reported they had a college or technical school education and a median income of $\$ 75,000-\$ 99,000$. Compared to the U.S. population, these visitors have higher education and income levels.

\section{Visitor Opinions about Refuges}

- At least $89 \%$ of visitors agreed they are satisfied with each of four key refuge offerings: services provided by employees or volunteers; recreational opportunities; refuge information and education; and the refuge's job of conserving fish, wildlife and their habitats.

- Visitors to the nine refuges in the study that charged a fee were satisfied with those fees, as $88 \%$ agreed that the opportunities and services were at least equal to the fee they paid and $82 \%$ felt the fee was about right. A small percentage of visitors felt the fee was too low or too high.

\section{Visitor Opinions about Alternative Transportation}

- More than half of visitors indicated they would be likely to use an offsite parking lot that provides trail access for walking/hiking onto the refuge, a boat that goes to different points on refuge waterways, and a bus or tram that runs during a special event.

\section{Visitor Opinions about Climate Change}

- Most visitors indicated they are personally concerned about climate-change effects on fish, wildlife and habitats. Just over half of visitors take actions to alleviate those effects and feel they stay wellinformed about the issue. Most visitors agreed that future generations will benefit if climate change effects on fish, wildlife and habitats are addressed; it is important to consider the economic costs and benefits to local communities when addressing these effects; and addressing these effects can improve our quality of life. 


\section{Introduction}

The National Wildlife Refuge System, established in 1903 and managed by the U.S. Fish and Wildlife Service (Service), is the leading network of protected lands and waters in the world dedicated to the conservation of fish, wildlife and their habitats. There are 556 national wildlife refuges (refuges) and 38 wetland management districts nationwide, including possessions and territories in the Pacific and Caribbean, encompassing more than 150 million acres. The mission of the Refuge System is to "administer a national network of lands and waters for the conservation, management and, where appropriate, restoration of the fish, wildlife, and plant resources and their habitats within the United States for the benefit of present and future generations of Americans." Part of achieving this mission is the goal "to foster understanding and instill appreciation of fish, wildlife, and plants, and their conservation, by providing the public with safe, high-quality, and compatible wildlife-dependent public use" (Clark, 2001). The Refuge System attracts nearly 45 million visitors annually, including 25 million people per year to observe and photograph wildlife, over 9 million to hunt and fish, and more than 10 million to participate in educational and interpretation programs (U.S. Fish and Wildlife Service, 2007). Understanding visitors and characterizing their experiences on refuges are critical elements of managing these lands and meeting the goals of the Refuge System.

The Service contracted with the U.S. Geological Survey (USGS) to conduct a national survey of visitors regarding their experiences on refuges. The survey was conducted to better understand visitor needs and experiences and to design programs and facilities that respond to those needs. The survey results will inform Service performance planning, budget, and communications goals. Results will also inform Comprehensive Conservation Plan (CCPs), Visitor Services, and Transportation Planning processes. The summary results reported herein are based on surveying at 53 participating refuges during 2010/2011 and are available at http://pubs.usgs.gov/ds/685/as part of USGS Data Series 685 (Sexton and others, 2012). Individual results for the 53 participating refuges are available at $h t t p: / / p u b s . u s g s . g o v / d s / 643 /$ as part of USGS Data Series 643 (Sexton and others, 2011).

\section{Methods}

\section{Selecting Participating Refuges}

The national wildlife refuge visitor survey was conducted from July 2010 to November 2011 on 53 refuges across the Refuge System (table 1; see also fig. 2). Based on the Refuge System's 2008 Refuge Annual Performance Plan (RAPP; U.S. Fish and Wildlife Service, 2011, written commun.), 192 refuges with a minimum annual visitation of 25,000 were considered for inclusion, because that number represents the median visitation across the Refuge System and the minimum visitation necessary to ensure that the surveying would be logistically feasible onsite. Visitation to these 192 refuges represents $88 \%$ of total visitation to all refuges in the Refuge System. We selected 35 refuges using a cluster random sampling approach, because the population of visitors to the Refuge System is divided into clusters (that is, refuges). Additionally, 18 refuges were selected by Service Regional Offices to respond to priority planning needs.

\section{Developing the Survey Instrument}

Researchers with the USGS developed the survey in consultation with the Service Headquarters Office, managers, planners, and visitor-services professionals. The survey was peer-reviewed by academic and government researchers and was further pre-tested with eight Refuge System Friends Group representatives, one from each region, to ensure readability and overall clarity. The survey and associated methodology were approved by the Office of Management and Budget (OMB control \#: 1018-0145; expiration date: 6/30/2013). 
Table 1. Participating refuges in the 2010/2011 national wildlife refuge visitor survey. Refuges with a single asterisk were not randomly selected; refuges with a double asterisk were sampled as one unit.

\begin{tabular}{|c|c|}
\hline \multicolumn{2}{|l|}{ Pacific Region (R1) } \\
\hline Kilauea Point National Wildlife Refuge (HI) & William L. Finley National Wildlife Refuge (OR)* \\
\hline Deer Flat National Wildlife Refuge (ID) & McNary National Wildlife Refuge (WA) \\
\hline Cape Meares National Wildlife Refuge (OR) & Turnbull National Wildlife Refuge (WA) \\
\hline \multicolumn{2}{|l|}{ Malheur National Wildlife Refuge (OR)* } \\
\hline \multicolumn{2}{|l|}{ Southwest Region (R2) } \\
\hline Bitter Lake National Wildlife Refuge (NM) & Aransas National Wildlife Refuge (TX)* \\
\hline Bosque del Apache National Wildlife Refuge (NM) & San Bernard/ Brazoria National Wildlife Refuge (TX)** \\
\hline \multicolumn{2}{|l|}{ Wichita Mountains Wildlife Refuge $(\mathrm{OK})^{*}$} \\
\hline \multicolumn{2}{|l|}{ Great Lakes-Big Rivers Region (R3) } \\
\hline DeSoto National Wildlife Refuge (IA) & Rice Lake National Wildlife Refuge (MN) \\
\hline Neal Smith National Wildlife Refuge (IA)* & Tamarac National Wildlife Refuge (MN)* \\
\hline \multirow{2}{*}{$\begin{array}{l}\text { McGregor District, Upper Mississippi River National } \\
\text { Wildlife and Fish Refuge (IA/WI) }\end{array}$} & Big Muddy National Fish and Wildlife Refuge (MO) \\
\hline & Horicon National Wildlife Refuge (WI) \\
\hline Muscatatuck National Wildlife Refuge (IN) & Necedah National Wildlife Refuge (WI) \\
\hline \multicolumn{2}{|l|}{ Southeast Region (R4) } \\
\hline Wheeler National Wildlife Refuge (AL) & Banks Lake National Wildlife Refuge (GA) \\
\hline Big Lake National Wildlife Refuge (AR) & Noxubee National Wildlife Refuge (MS) \\
\hline Pond Creek National Wildlife Refuge (AR) & Cabo Rojo National Wildlife Refuge (Puerto Rico)* \\
\hline Merritt Island National Wildlife Refuge (FL) & Pea Island National Wildlife Refuge (NC) \\
\hline St. Marks National Wildlife Refuge (FL)* & Cape Romain National Wildlife Refuge (SC) \\
\hline Ten Thousand Islands National Wildlife Refuge (FL) & Reelfoot National Wildlife Refuge (TN) \\
\hline \multicolumn{2}{|l|}{ Northeast Region (R5) } \\
\hline Stewart B. McKinney National Wildlife Refuge (CT) & Moosehorn National Wildlife Refuge (ME) \\
\hline Bombay Hook National Wildlife Refuge (DE) & Great Swamp National Wildlife Refuge (NJ)* \\
\hline Monomoy National Wildlife Refuge (MA) & Montezuma National Wildlife Refuge (NY)* \\
\hline Parker River National Wildlife Refuge (MA) & Wertheim National Wildlife Refuge (NY) \\
\hline Patuxent Research Refuge (MD) & $\begin{array}{l}\text { Occoquan Bay/Elizabeth Hartwell Mason Neck } \\
\text { National Wildlife Refuge (VA)** }\end{array}$ \\
\hline \multicolumn{2}{|l|}{ Mountain-Prairie Region (R6) } \\
\hline Monte Vista National Wildlife Refuge (CO)* & Sand Lake National Wildlife Refuge (SD)* \\
\hline Quivira National Wildlife Refuge (KS)* & National Elk Refuge (WY) \\
\hline \multicolumn{2}{|l|}{ Charles M. Russell National Wildlife Refuge (MT) } \\
\hline \multicolumn{2}{|l|}{ Alaska Region (R7) } \\
\hline Alaska Maritime National Wildlife Refuge (AK) & Kenai National Wildlife Refuge (AK)* \\
\hline \multicolumn{2}{|l|}{ California and Nevada Region (R8) } \\
\hline Lower Klamath/Tule Lake National Wildlife Refuge (CA)** & Ruby Lake National Wildlife Refuge (NV)* \\
\hline Sonny Bono Salton Sea National Wildlife Refuge (CA) & \\
\hline
\end{tabular}




\section{Contacting Visitors}

Each participating refuge followed a common sampling protocol. Refuge staff identified two separate 15-day sampling periods and one or more locations that best reflected the diversity of use and specific visitation patterns at each refuge. Sampling periods and locations were identified by refuge staff and submitted to USGS via an internal website that included a customized mapping tool. A standardized sampling schedule (that included eight randomly selected sampling shifts during each of the two sampling periods) was created for all refuges. Sampling shifts were three- to five-hour randomly selected time bands that were stratified across AM (beginning before noon) and PM (beginning after noon) hours, as well as weekends and weekdays. Any necessary customizations were made to the standardized schedules (in coordination with refuge staff) to accommodate each refuge's patterns of visitation and facility logistics (for example, visitor center days and hours of operation) and any unforeseen environmental conditions (for example, bad weather or flooding).

Twenty visitors (18 years or older) per sampling shift were systematically selected, for a total of 320 willing participants per refuge-160 per sampling period — to ensure an adequate sample of completed surveys. When necessary, shifts were moved, added, or extended to alleviate logistical limitations (for example, weather or low visitation at a particular site) in an effort to reach target numbers. Refuge staff and/or volunteers (survey recruiters) contacted visitors on-site using a standard protocol provided by USGS to ensure a diverse sample. Instructions included contacting visitors across the entire sampling shift (for example, every $\mathrm{n}^{\text {th }}$ visitor for dense visitation, as often as possible for sparse visitation), and only one person per group. Visitors were informed of the survey effort, given a token incentive (for example, a small magnet or a temporary tattoo), and asked to participate. Willing participants provided their name, mailing address, and preference for language (English or Spanish) and survey mode (mail or online). Survey recruiters also were instructed to record any refusals and then proceed with the sampling protocol.

Visitors were mailed a postcard within 10 days of the initial on-site contact thanking them for agreeing to participate in the survey and inviting them to complete the survey online. Those visitors choosing not to complete the survey online were sent a paper copy a week later. Two additional contacts were made by mail during the next seven weeks following a modified Tailored Design Method (Dillman, 2007): (1) a reminder postcard one week after the first survey, and (2) a second paper survey two weeks after the reminder postcard. Each mailing included instructions for completing the survey online and a postage-paid envelope for returning the paper version of the survey. Those visitors indicating a preference for Spanish were sent Spanish versions of all correspondence (including the survey). Finally, a short survey of six questions was sent to nonrespondents four weeks after the second survey mailing to determine any differences between respondents and nonrespondents. Online survey data were exported and paper survey data were entered using a standardized survey codebook and data entry procedure. All survey data were analyzed using SPSS v. $18^{1}$ statistical analysis software.

\section{Interpreting the Results}

A total of 14,832 visitors agreed to participate in the survey after being contacted at participating refuges between July 2010 and November 2011. In all, 10,233 visitors completed the survey for a 71\% response rate. According to Babbie (2010), a response rate of $70 \%$ or greater is very good. Half of the respondents completed the survey online and half completed a paper survey. Chi squared, t-test, and effectsize analyses revealed no statistically significant differences (at $\mathrm{p} \leq .05$ and eta, phi, or Cramer's $\mathrm{V} \geq .1$ ) between aggregated responses from visitors to the 35 randomly selected and 18 other refuges on any of the

\footnotetext{
${ }^{1}$ Any use of trade, product, or firm names is for descriptive purposes only and does not imply endorsement by the U.S. Government.
} 
measured variables; therefore, data from all 53 refuges were combined into one dataset for reporting these results. This combined data set was then proportionately weighted to account for the variation in sample size and the 2011 annual visitation of each refuge (U.S. Fish and Wildlife Service, 2011, written commun.). The number of completed surveys (sample size) from visitors to each refuge ranged from 85 to 276 . This variation in sample size is attributable to each refuge's ability to contact the targeted 320 visitors and the response rate for each refuge. Additionally, a nonresponse-bias check was conducted to detect differences in responses between visitors who completed the survey and those who did not. Using Chi squared analysis, we compared responses to six questions sent to visitors who did not respond to the full survey (nonrespondents) to the responses of visitors who completed the full survey. We found no statistically significant differences (at $\mathrm{p} \leq .05$ and phi or Cramer's $\mathrm{V} \geq .1$ ) between respondents and nonrespondents on any of the variables measured.

\section{Limitations}

Two important limitations exist for this study: first, only refuges with at least 25,000 annual visitors based on the 2008 RAPP (U.S. Fish and Wildlife Service, 2011, written comm.) were considered for selection, so not all refuges in the Refuge System were included in the sample population. Second, refuges were sampled on randomly selected days during two separate 15-day periods that were selected by refuge staff. Guidance was given to refuge staff to choose sampling periods that best represented the diversity of visitors at their refuge over the course of a year. This design encouraged sampling to occur when sufficient numbers of visitors were onsite to achieve sampling targets. However, there are spatial and temporal limitations to this method; consequently, not all visitors over the course of the year had an equal chance of selection.

In light of these limitations, we explored the extent to which sampling across the Refuge System encompassed the seasons of the year and different refuge activities (hunting, fishing, wildlife observation, photography, interpretation and environmental education). Refuges were sampled during all seasons: $42 \%$ of refuges were sampled in summer, $66 \%$ in fall, $21 \%$ in winter and $56 \%$ in spring. During summer, refuges from all regions were sampled, while fall included 7 of the 8 regions, winter included 5 regions, and spring included 7 regions. Refuges and regions occurring in more northern latitudes were better represented during the spring, summer and fall months when visitation is not limited by ice/snow/harsh conditions.

Additionally, all refuges sampled visitors in 2 different seasons except for 8 refuges, which sampled visitors during 1 season ( 5 refuges sampled visitors in summer only and 3 in fall only). In terms of activities, all sampled refuges that provide fishing, wildlife observation, photography, interpretation and environmental education had survey responses from visitors who had participated in those activities in the 12-month period before they were contacted. Only one of the sampled refuges that provide hunting opportunities (Stewart B. McKinney NWR) did not have survey responses from hunters. Based on the RAPP (U.S. Fish and Wildlife Service, 2011, written commun.), this activity represents less than $0.2 \%$ of the total visitation to Stewart B. McKinney NWR. Though these analyses show a diversity of visitors across seasons and activities in the sample, results may not apply to visitors to refuges during all times of the year, to visitors who did not visit the survey locations, or to refuges that did not participate in the survey. 


\section{Survey Results}

\section{Visitor and Trip Characteristics}

A solid understanding of refuge visitors and details about their trips to refuges can inform communication outreach efforts, inform visitor services and transportation planning, forecast use, and gauge demand for services and facilities.

\section{Familiarity with the National Wildlife Refuge System}

While we did not ask visitors to identify the mission of the National Wildlife Refuge System or the U.S. Fish and Wildlife Service, visitors to refuges reported that before participating in the survey, they were aware of the role of the U.S. Fish and Wildlife Service in managing national wildlife refuges $(86 \%)$ and that the Refuge System has the mission of conserving, managing, and restoring fish, wildlife, plants and their habitat (90\%). Positive responses to these questions concerning the management and mission of the Refuge System do not indicate the degree to which these visitors understand the day-to-day management practices of refuges, only that visitors feel they have a basic knowledge of who manages refuges and why. Many visitors feel that refuges provide a unique recreation experience $(86 \%)$, compared to other public lands; however, reasons why visitors find refuges unique are varied and may not directly correspond to their understanding of the mission of the Refuge System. Most visitors had been to at least two national wildlife refuges in the past year $(61 \%)$, with an average of 5 visits to refuges other than the one where they were contacted during that time. Some of these visits may have been repeat visits to the same refuge.

\section{Visiting Refuges}

Most visitors (59\%) went to the same refuge multiple times during the 12 -month period before they were contacted to participate in this survey, whereas some (39\%) had visited only once. Repeat visitors went to the refuge where they were contacted an average of 14 times during that same 12-month period. Visitors used refuges during only one season (53\%), during multiple seasons (26\%), and year-round (21\%). Most visitors first learned or heard about refuges from friends/relatives $(50 \%)$, signs on the highway $(28 \%)$, people in the local community (19\%), and refuge printed information (16\%; fig. 1$)$.

Some visitors (42\%) indicated they lived in the local area (within 50 miles of a refuge), whereas $58 \%$ were nonlocal visitors. Local visitors traveled an average of 22 miles to get to the refuge where they were contacted, while nonlocal visitors traveled an average of 440 miles. Figure 2 shows the median distance traveled by visitors to each participating refuge. As dot size increases, the number of miles travelled increases. Thirty-one refuges had more local visitors than nonlocal visitors (as indicated by the smallest dot); 22 refuges had more nonlocal visitors than local visitors (as indicated by the three larger dots). 


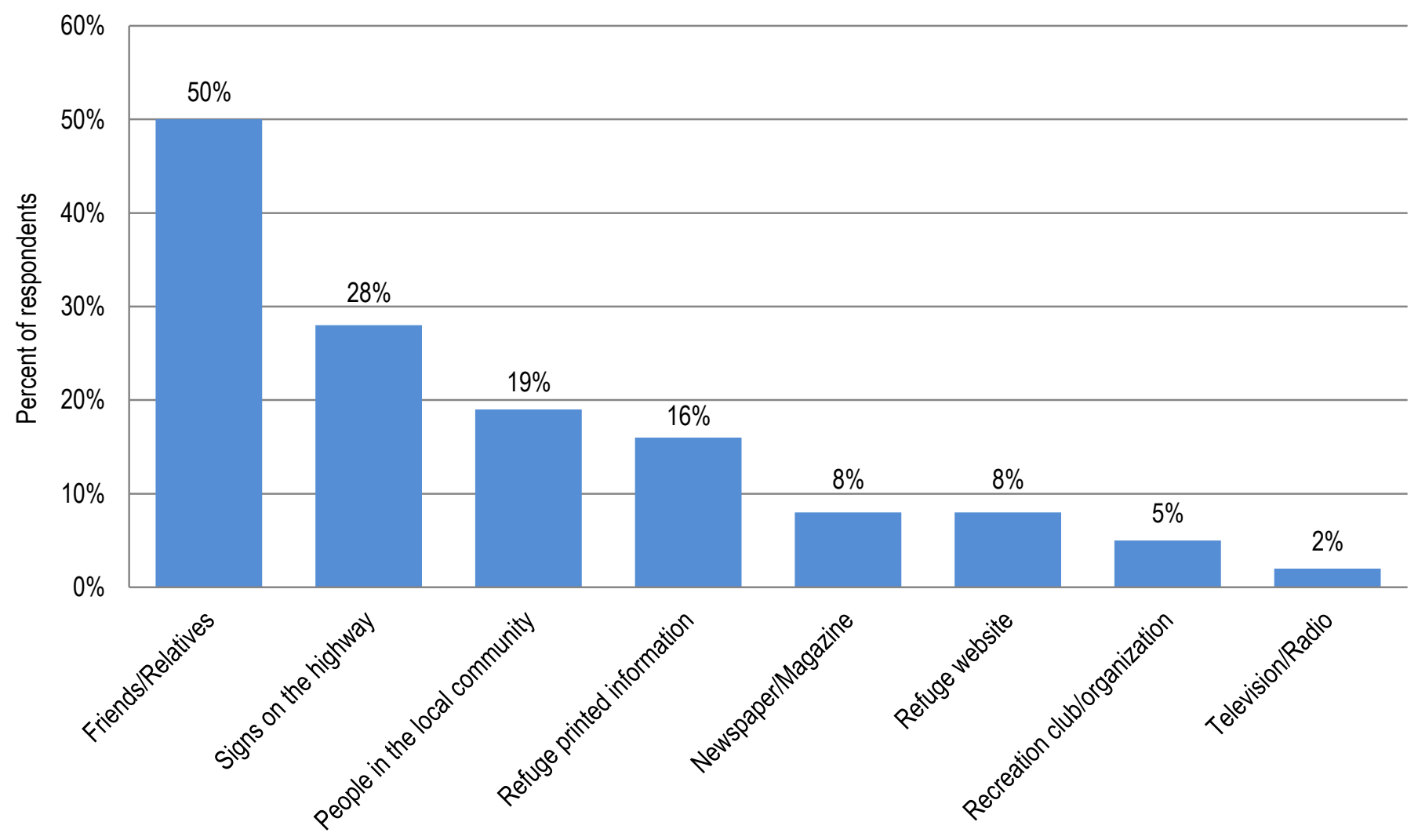

Figure 1. How visitors first learned or heard about refuges $(n=9,774)$. 


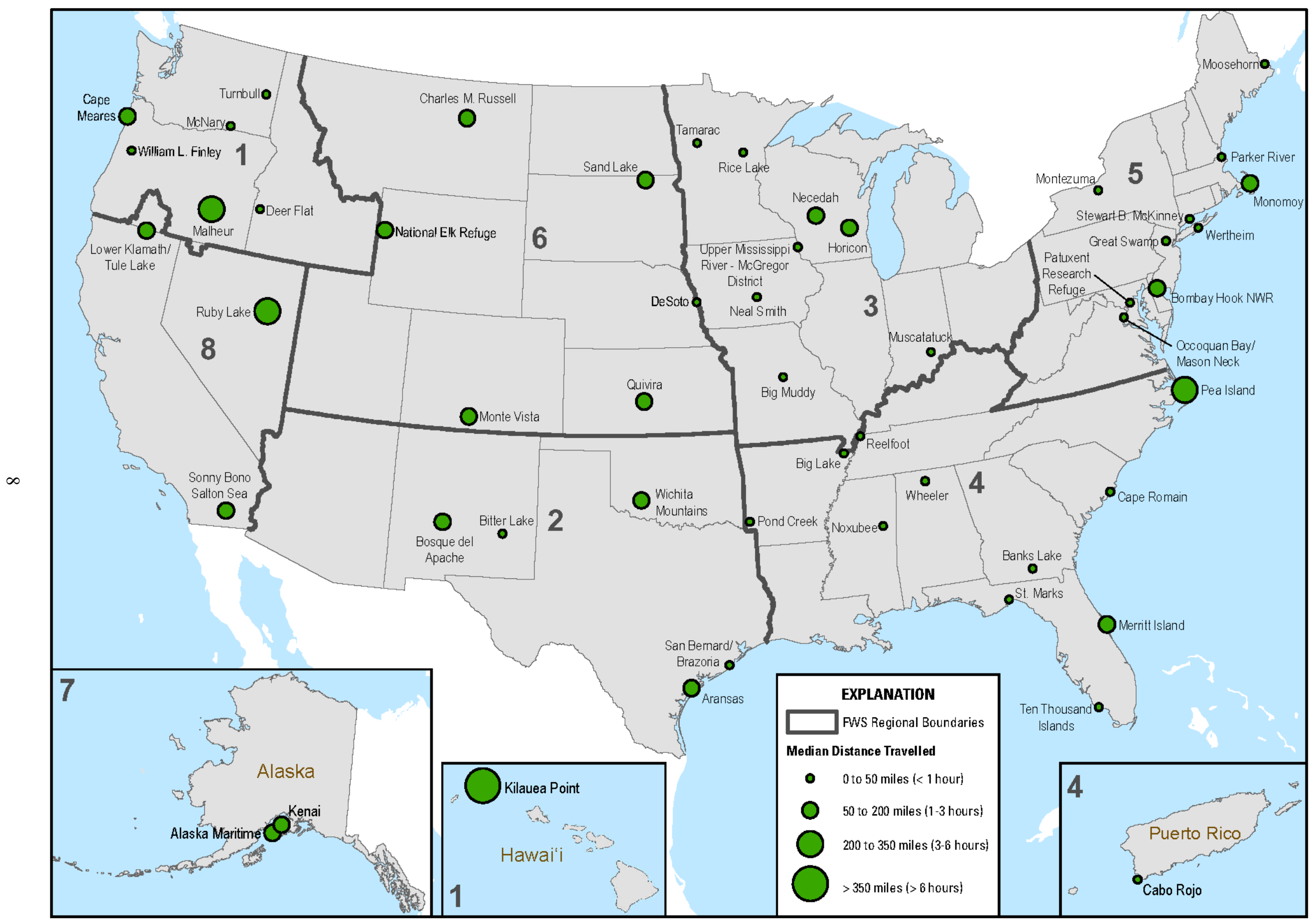

Figure 2. Median distance travelled (and approximate travel times) by visitors to each participating national wildlife refuge $(n=10,178)$. 
For most local and nonlocal visitors, refuges were the primary purpose or sole destination of their trip ( $78 \%$ and $40 \%$, respectively; table 2). Nonlocal visitors stayed in the local area for 4 days, on average. Key information sources used by visitors to find their way to refuges include previous knowledge (53\%) and signs on highways (45\%; fig. 3).

Table 2. Influence of refuges on visitors' decision to take their trips $(n=9,858)$.

\begin{tabular}{lccc}
\hline \multirow{2}{*}{ Visitors } & \multicolumn{3}{c}{ Visiting this refuge was... } \\
\cline { 2 - 4 } & $\begin{array}{c}\text { the primary reason } \\
\text { for trip }\end{array}$ & $\begin{array}{c}\text { one of many equally } \\
\text { important reasons for trip }\end{array}$ & an incidental stop \\
\hline Nonlocal & $40 \%$ & $37 \%$ & $23 \%$ \\
Local & $78 \%$ & $13 \%$ & $9 \%$ \\
Total & $56 \%$ & $27 \%$ & $17 \%$ \\
\hline
\end{tabular}

${ }^{1}$ An example of an equally important reason would be a visitor who takes a trip to visit both National Elk Refuge and Yellowstone National Park.

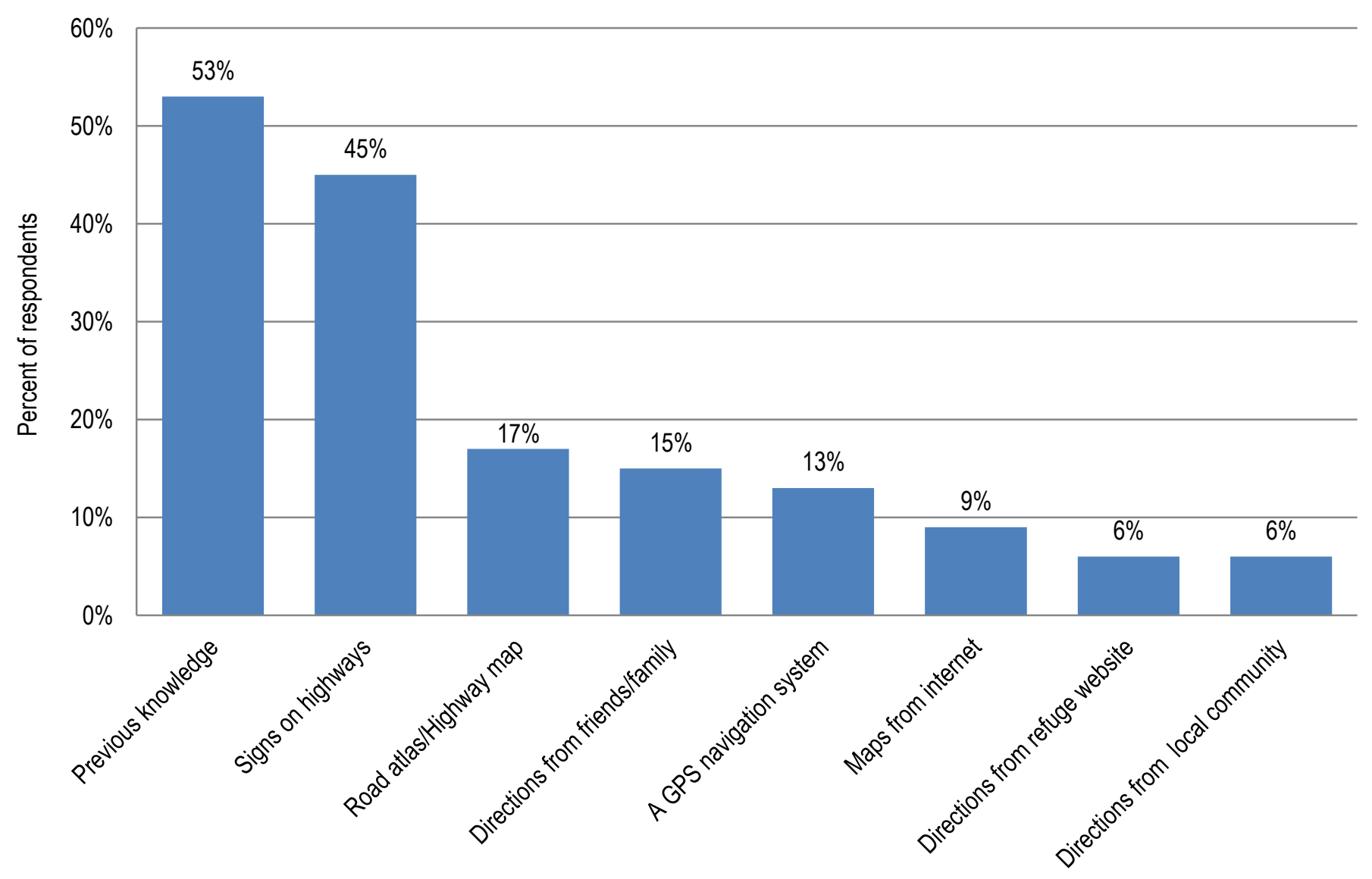

Figure 3. Resources used by visitors to find their way to refuges $(n=10,061)$. 
Visitors spent an average of 5 hours at refuges during one day there (a day visit is assumed to be 8 hours). However, the most frequently reported length of visit during one day was actually 8 hours $(35 \%)$. The key modes of transportation used by visitors to travel around refuges were private vehicle (79\%) and walking/hiking ( $25 \%$; fig. 4). Most visitors traveled to refuges as part of a group $(65 \%)$, travelling primarily with family and friends (table 3 ).

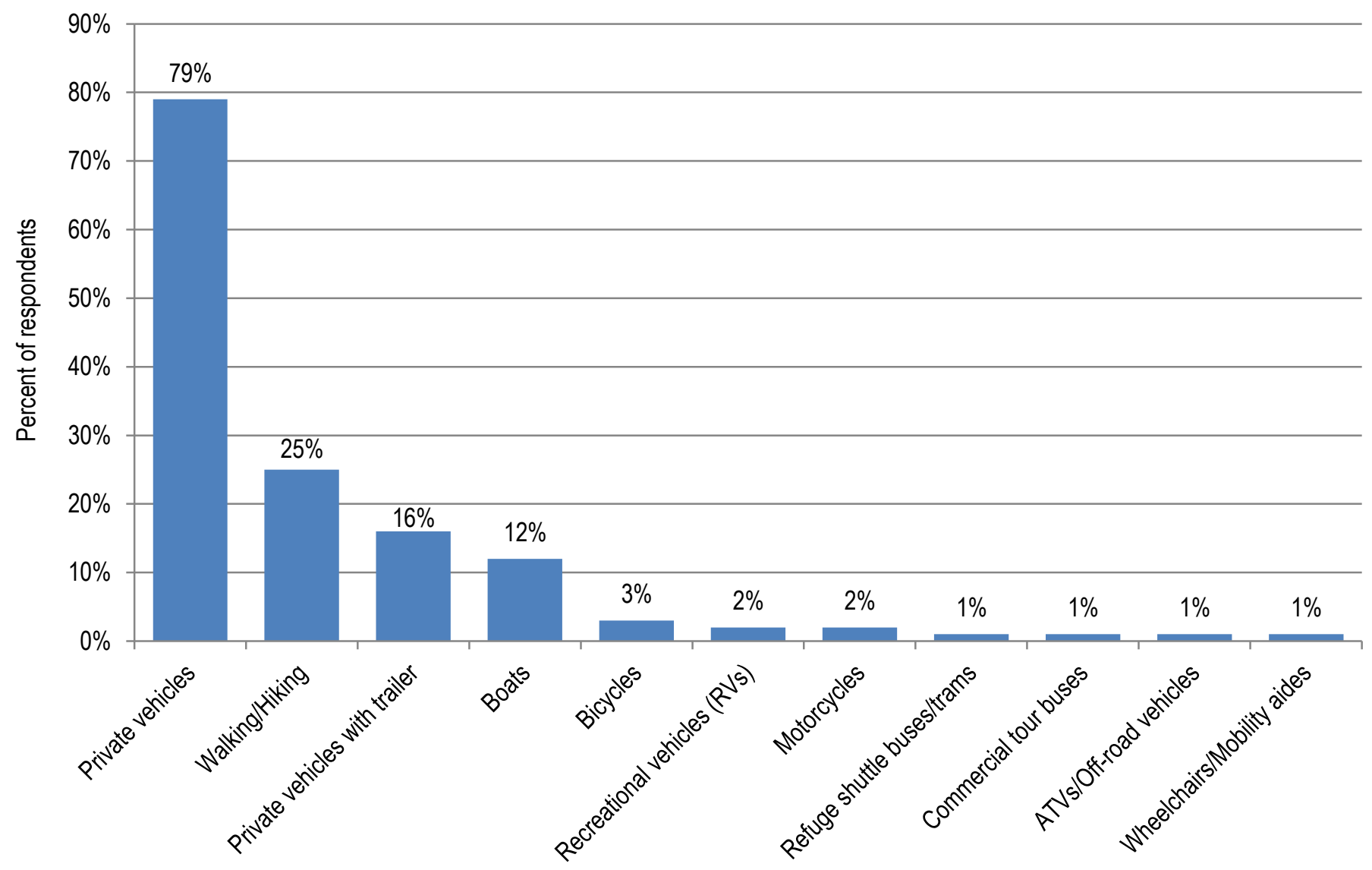

Figure 4. Modes of transportation used by visitors on refuges $(n=10,099)$.

Table 3. Type and size of groups visiting refuges (for those who indicated they were part of a group, $n=6,544$ ).

\begin{tabular}{lcccc}
\hline \multirow{2}{*}{ Group type } & $\begin{array}{c}\text { Percent } \\
\text { (of those traveling } \\
\text { in a group) }\end{array}$ & Number of adults & Number of children & Total group size \\
\cline { 3 - 5 } & $90 \%$ & 3 & 1 & 4 \\
\hline Family/Friends & $1 \%$ & 13 & 1 & 14 \\
Commercial tour group & $5 \%$ & 12 & 11 & 23 \\
Organized club/School group & $4 \%$ & 14 & 3 & 17 \\
Other group type & & & & Average group size \\
\hline
\end{tabular}


Visitors participated in a variety of refuge activities during the12-month period before they were contacted (fig. 5); the top three activities reported were wildlife observation (60\%), bird watching (49\%), and photography (44\%). The top three activities visitors reported as their primary reason for their most recent visit included wildlife observation (18\%), bird watching (16\%), and fishing (15\%; fig. 6). Refuge visitor centers were used by $64 \%$ of visitors to the 46 refuges surveyed that have visitor centers mostly to view the exhibits ( $80 \%$ ), stop to use the facilities (for example, get water, use the restroom; 69\%), ask information of staff/volunteers (65\%), and visit the gift shop/bookstore (65\%; fig. 7).

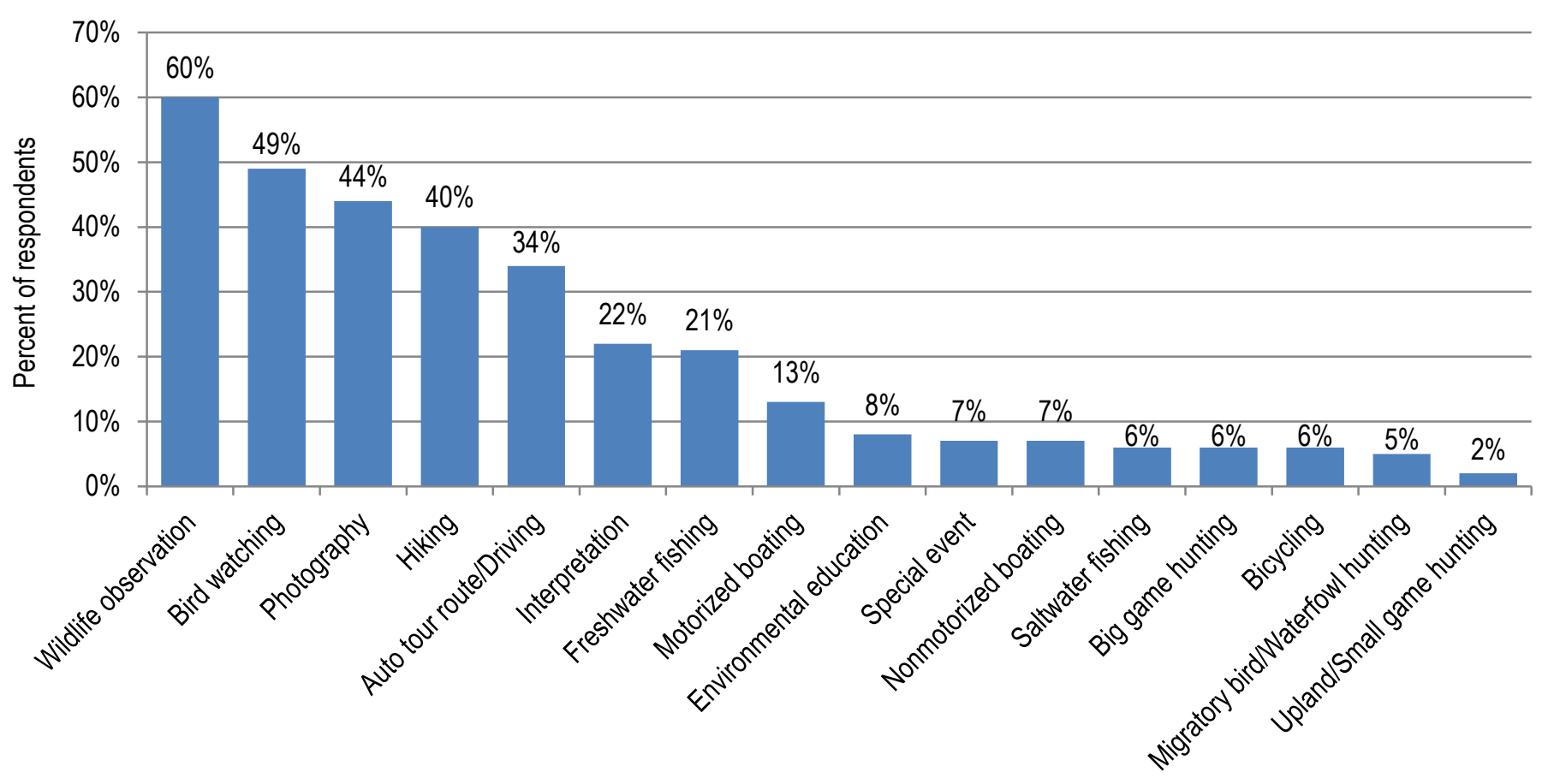

Figure 5. Activities in which visitors participated on refuges during the 12-month period before they were contacted. $(n=10,041)$.

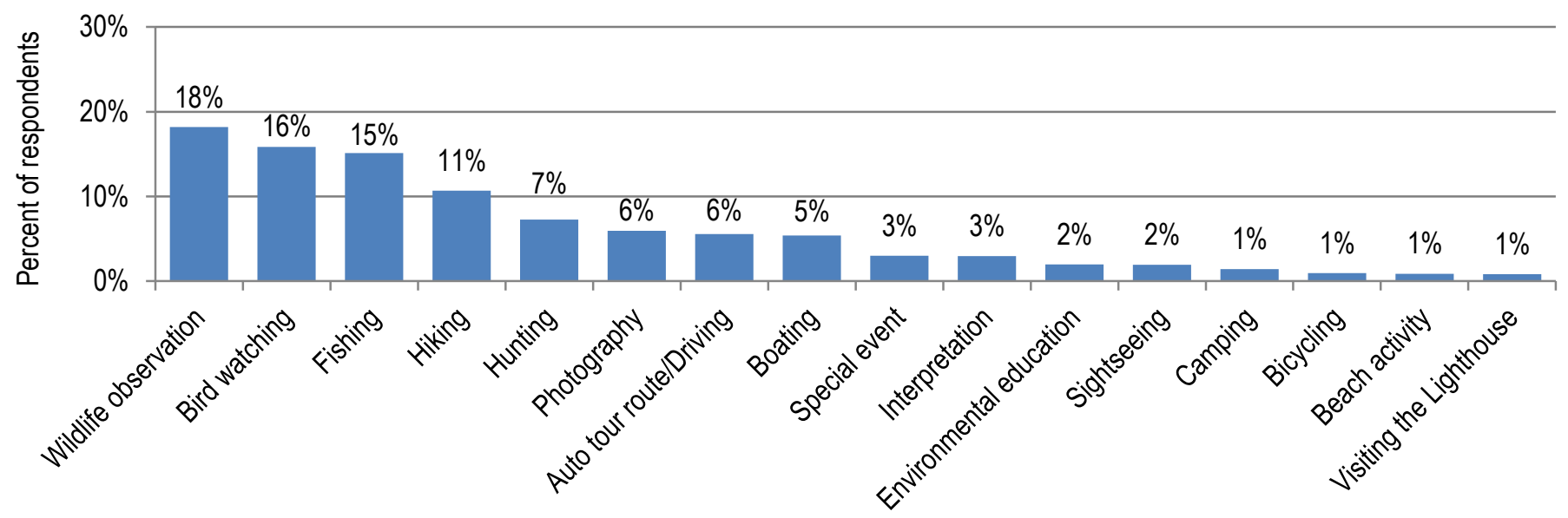

Figure 6. The primary activity in which visitors participated during their visits $(n=9,225)$. 


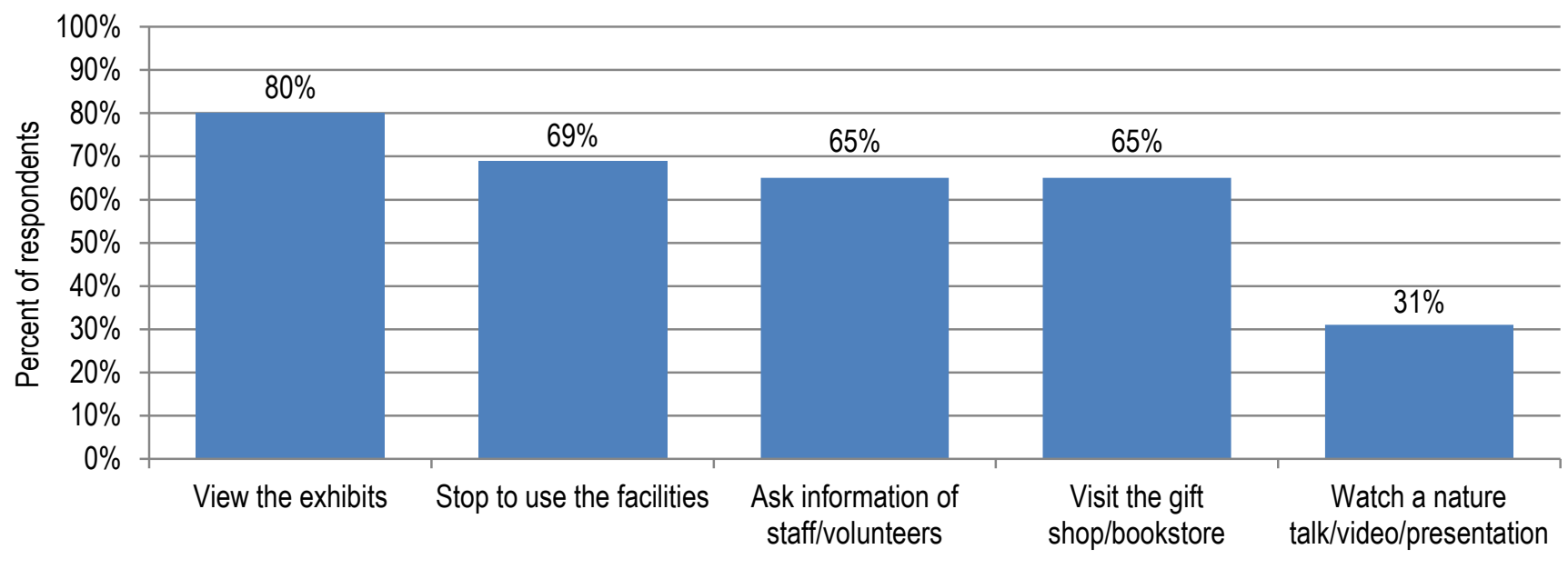

Figure 7. Use of visitor centers at refuges with visitor centers (for those visitors who used the visitor center, $n=6,320$ ). Not every refuge with a visitor center had all of these offerings.

\section{Visitor Characteristics}

Nearly all $(98 \%)$ visitors indicated that they were citizens or permanent residents of the United States. Only visitors 18 years or older were sampled. Visitors were a mix of 58\% male with an average age of 54 years and $42 \%$ female with an average age of 52 years. Visitors, on average, reported they had 15 years of formal education (college or technical school). The median level of income was $\$ 75,000-\$ 99,000$ (table 4). In comparison, the 2006 National Survey of Fishing, Hunting and Wildlife-Associated Recreation found that participants in wildlife watching and hunting on public land were $55 \%$ male and $45 \%$ female with an average age of 46 years, an average level of education of 14 years (associate degree or two years of college), and a median income of \$50,000-\$74,999 (Harris, 2011, written comm.). Compared to the 2006 U.S.

population, these 2006 survey participants were more likely to be male, older, and have higher education and income levels (U.S. Department of the Interior and U.S. Department of Commerce, 2007).

Table 4. Visitor demographics.

\begin{tabular}{lc}
\hline Demographic & Percent/Average \\
\hline Average age & 56 \\
Male & $58 \%$ \\
Female & $42 \%$ \\
Average education & college or technical school \\
Median household income & $\$ 75,000-99,000$ \\
Race & \\
$\quad$ American Indian or Alaska Native & $4 \%$ \\
$\quad$ Asian & $1 \%$ \\
$\quad$ Black or African American & $1 \%$ \\
$\quad$ Native Hawaiian or Pacific Islander & $1 \%$ \\
$\quad$ White & $96 \%$ \\
Hispanic or Latino ethnicity & $4 \%$ \\
\hline
\end{tabular}




\section{Visitor Opinions about Refuges}

National wildlife refuges provide visitors with a variety of services, facilities, and wildlife-dependent recreational opportunities. Understanding visitors' perceptions of their refuge experiences is a key component of the Refuge System mission as it pertains to providing high-quality wildlife-dependent recreational opportunities. Having a baseline understanding of visitor experiences can inform management decisions to better balance visitors' expectations with the Refuge System mission. Recent studies in outdoor recreation have included an emphasis on declining participation in traditional activities such as hunting and an increasing need to connect the next generation to nature and wildlife. These factors highlight the importance of current refuge visitors as a key constituency in wildlife conservation. A better understanding is increasingly needed to better manage visitor experiences and to address the challenges of the future.

Visitors' overall satisfaction with the services, facilities, and recreational opportunities provided at refuges were as follows (fig. 8):

- $91 \%$ were satisfied with the recreational activities and opportunities,

- $89 \%$ were satisfied with the information and education about the refuge and its resources,

- $91 \%$ were satisfied with the services provided by employees or volunteers, and

- $91 \%$ were satisfied with the refuge's job of conserving fish, wildlife and their habitats.

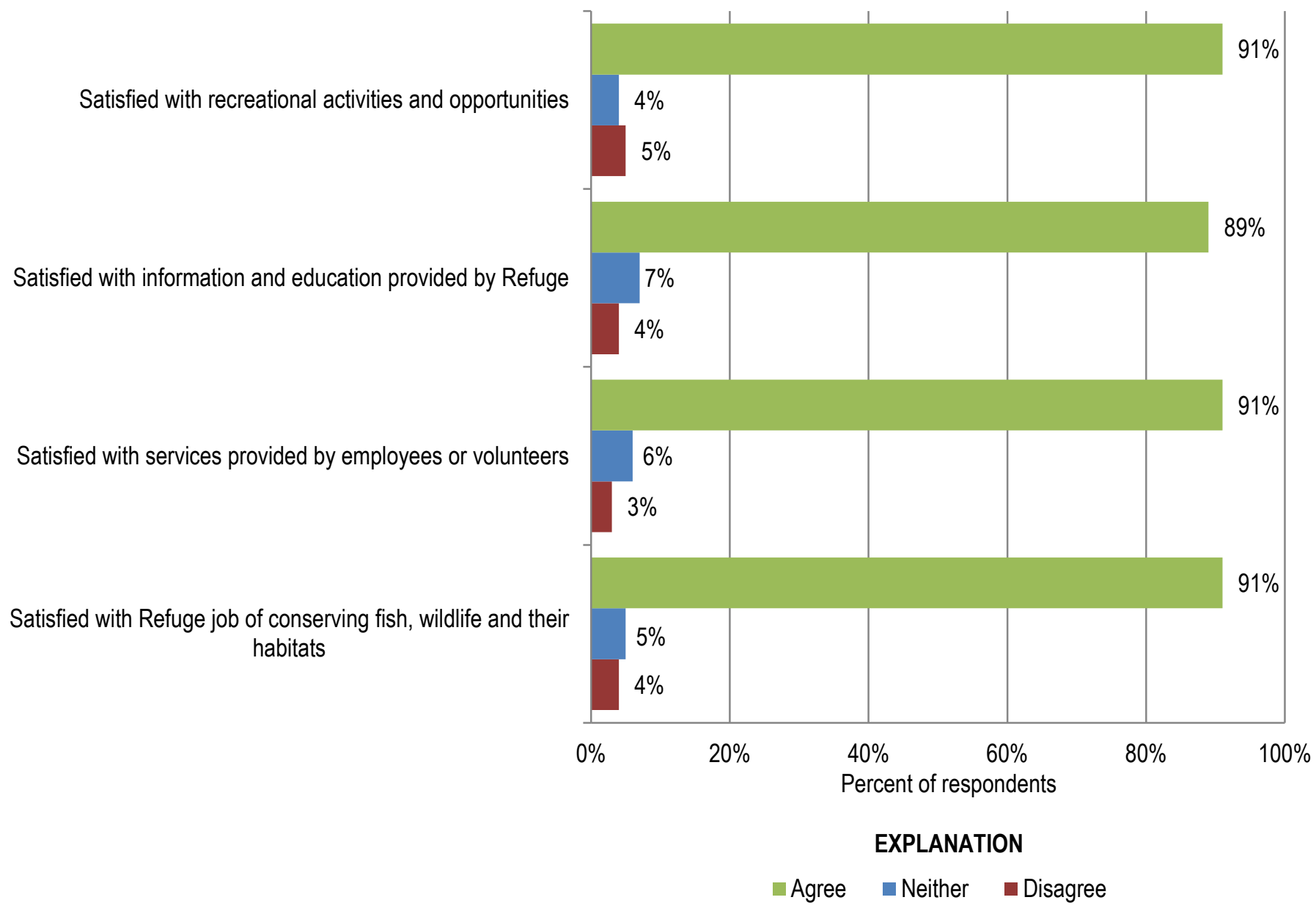

Figure 8. Overall satisfaction with refuges $(n \geq 9,478)$. 
Entrance fees are charged at 39 refuges in the Refuge System (U.S. Fish and Wildlife Service, 2011, written commun.), and generally range from \$2-\$5 per person for daily use. Seventy-six percent of visitors indicated that they paid a fee to enter one of the 9 surveyed refuges that charged an entrance fee. Of those, $88 \%$ agreed that the opportunities and services were at least equal to the fee they paid; $82 \%$ felt the fee was about right, whereas $14 \%$ felt that the fee was too low, and $4 \%$ felt it was too high (fig. 9).
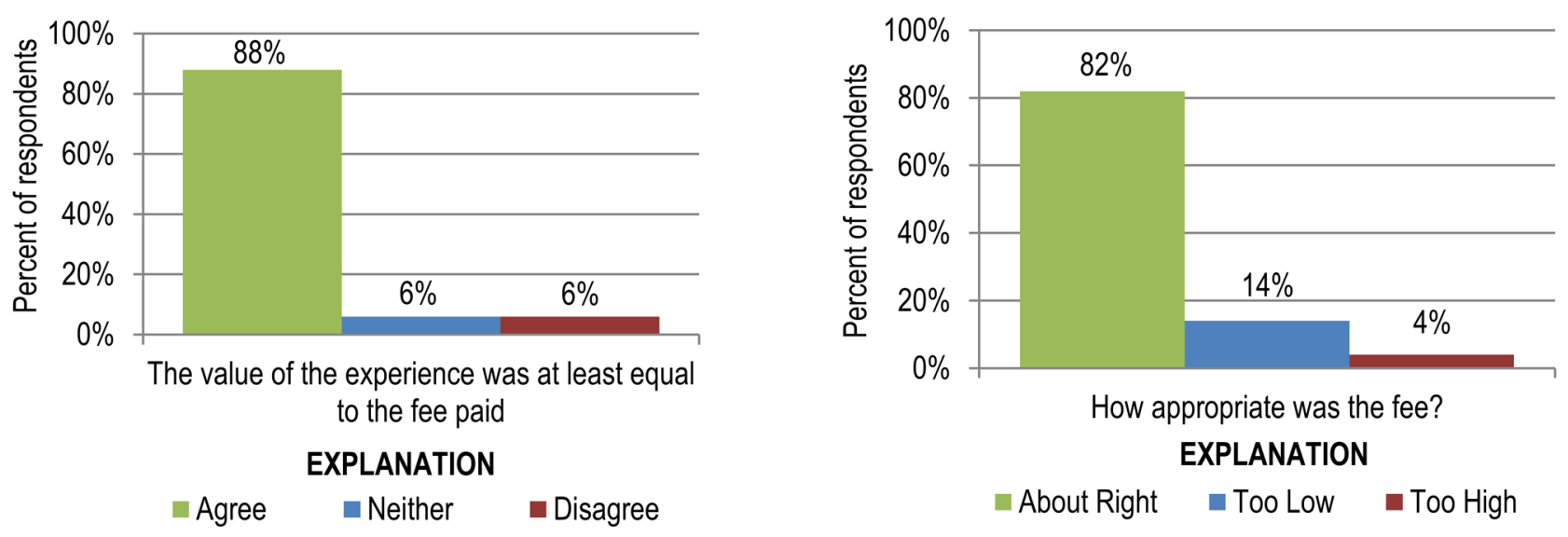

Figure 9. Opinions about fees at refuges that charge an entrance fee (for those visitors who indicated they paid a fee, $\mathrm{n}=2,467)$.

\section{Importance/Satisfaction Ratings}

Comparing the importance and satisfaction ratings for visitor services provided by refuges can help to identify how well the services are meeting visitor expectations. The importance-performance framework presented in this section is a tool that includes the importance of an attribute to visitors in relation to their satisfaction with that attribute. Drawn from marketing research, this tool has been applied to outdoor recreation and visitation settings (Martilla and James, 1977; Tarrant and Smith, 2002). Results for the attributes of interest are segmented into one of four quadrants (modified for this national study):

- Keep Up the Good Work = high importance/high satisfaction;

- Concentrate Here = high importance/low satisfaction;

- Low Priority = low importance/low satisfaction; and

- Look Closer = low importance/high satisfaction.

Graphically plotting visitors' importance and satisfaction ratings for different services, facilities, and recreational opportunities provides a simple and intuitive visualization of these survey measures. However, this tool is not without its drawbacks. One is the potential for variation among visitors regarding their expectations and levels of importance (Vaske and others, 1996; Bruyere and others, 2002; Wade and Eagles, 2003), and certain services or recreational opportunities may be more or less important for different segments of the visitor population. For example, hunters may place more importance on hunting opportunities and amenities such as blinds, while school group leaders may place more importance on educational/informational displays than would other visitors.

Figures 10-12 depict visitors' importance-satisfaction results for refuge services and facilities, recreational opportunities, and transportation-related features at all participating refuges, respectively. All services and facilities at refuges fell in the "Keep Up the Good Work" quadrant (fig. 10). 


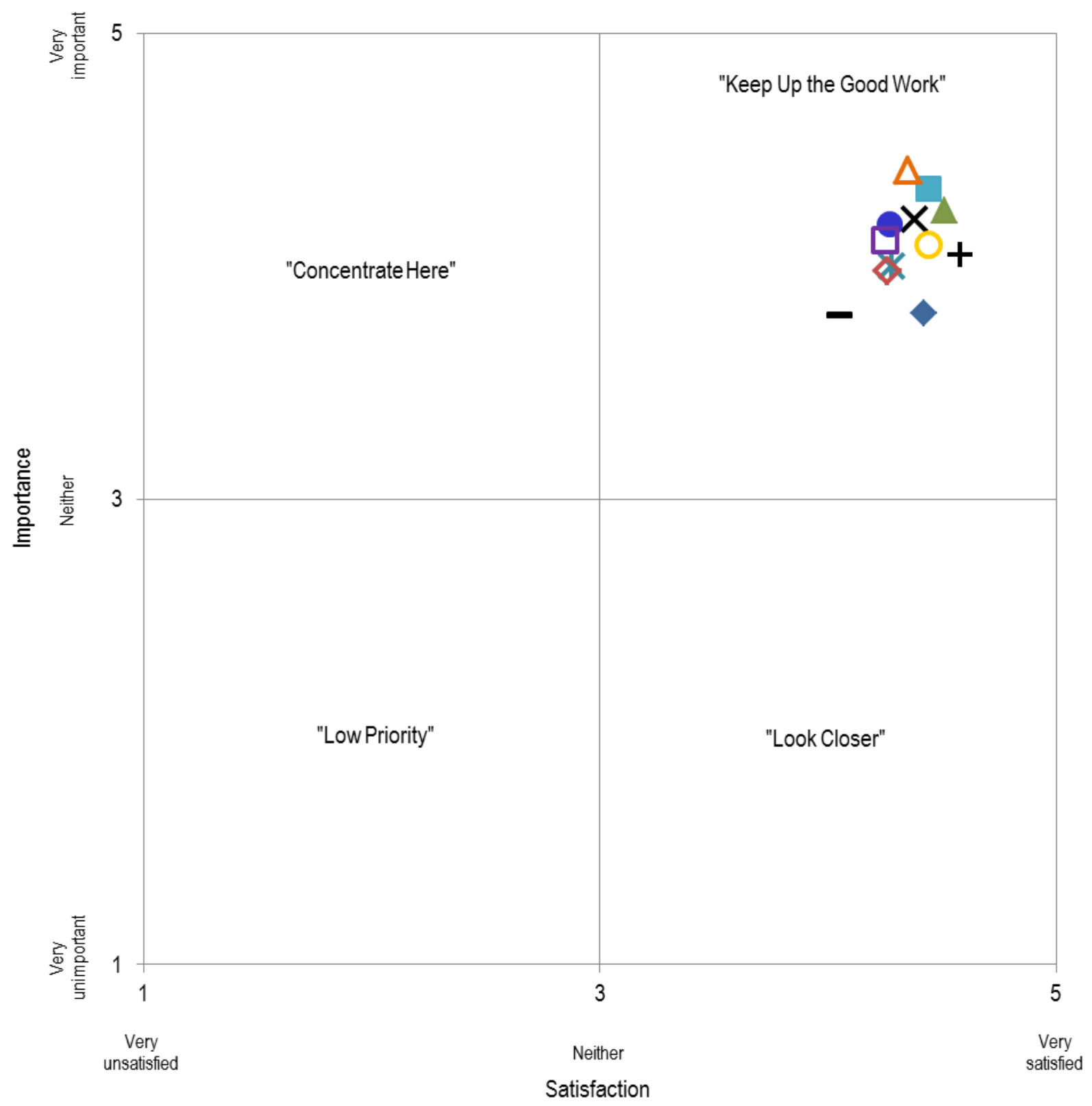

\section{EXPLANATION}

Convenient hours/days of operation

- Availability of employees/volunteers

+Courteous/welcoming employees/volunteers

$\Delta$ Knowledgeable employees/volunteers

XPrinted information about this Refuge

×Informational kiosks/displays about this Refuge

-Signs with rules/regulations

$\triangle$ Exhibits about this Refuge

-Environmental education programs/activities

OVisitor Center

$\triangle$ Well-maintained restrooms

口Wildlife observation structures

Figure 10. Importance-satisfaction ratings of services and facilities provided at refuges. 
All recreational opportunities at refuges fell in the "Keep Up the Good Work" quadrant for those who participated in those activities during the 12-month period before they were contacted (fig. 11). Importance ratings were lower for those who did not participate in hunting and fishing activities during the 12-month period before they were contacted (mean importance score $=2.28$ and 2.69, respectively).

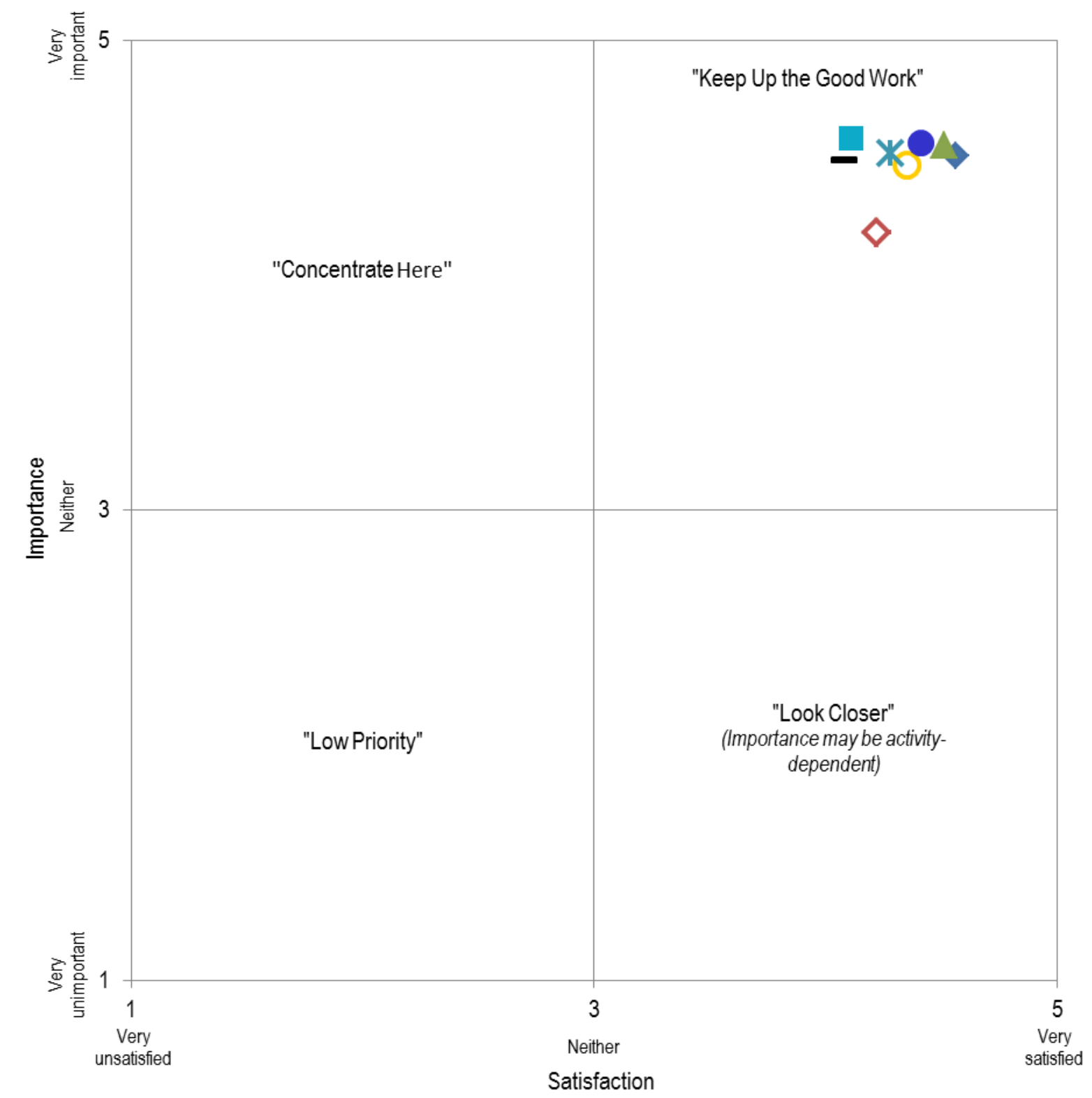

\section{EXPLANATION}

•Bird watching opportunities OWildlife viewing opportunities $\Delta$ Photography opportunities $\quad$ Hunting opportunities

xFishing opportunities $\quad$ Hiking opportunities $\quad$ Kayak/Canoe opportunities -Bicycling opportunities

Figure 11. Importance-satisfaction ratings of recreational opportunities provided at refuges for visitors participating in those activities. 
All transportation-related features at refuges fell in the "Keep Up the Good Work" quadrant. (fig. 12).

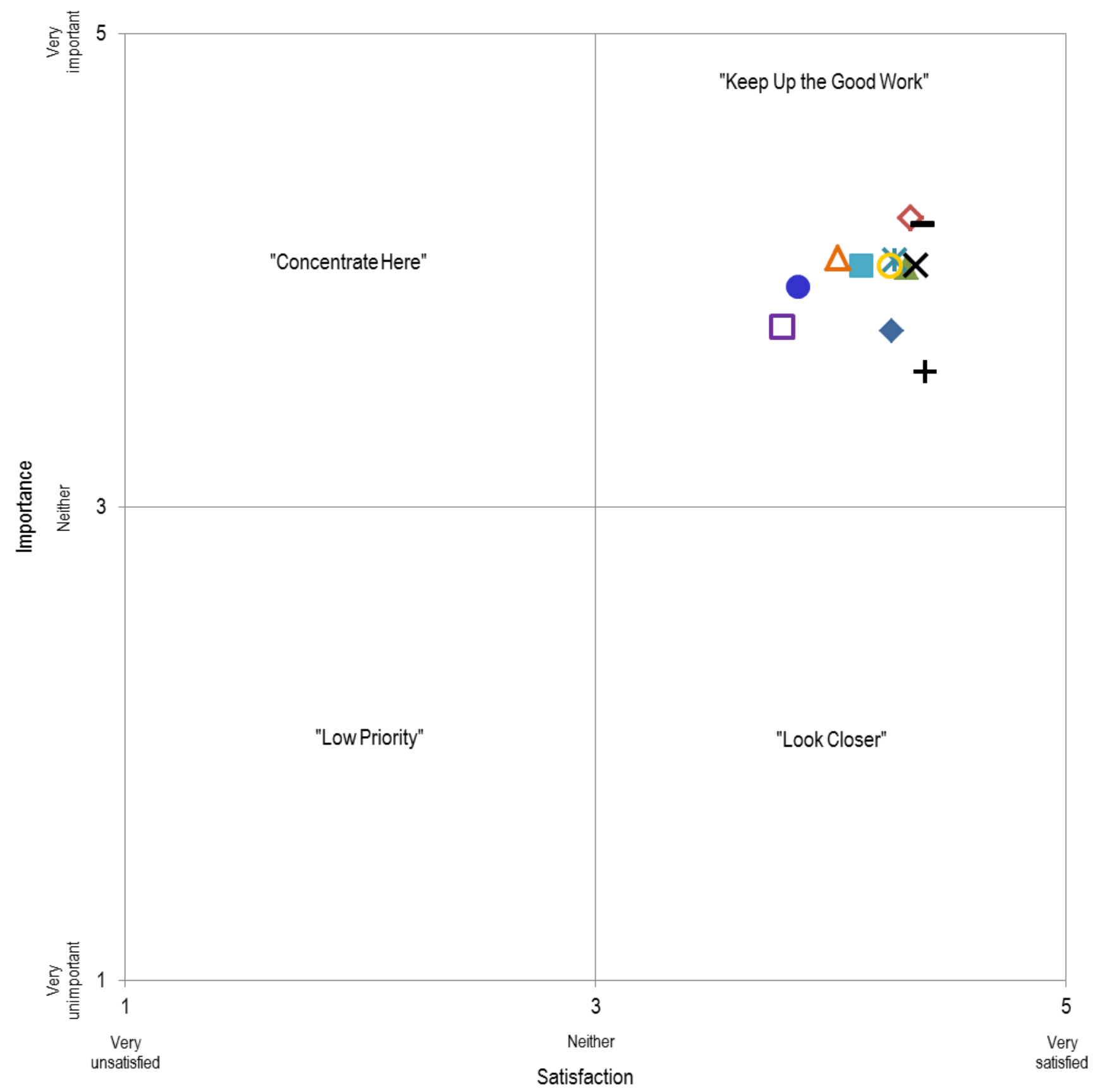

\section{EXPLANATION}

$\checkmark$ Condition of roads

Number of parking places

O Directional signs on highways
+ Condition of parking areas

- Number of pullovers

Directional signs on Refuge $\triangle$ Condition of bridges

S Safety of driving conditions

$\Delta$ Directional signs on trails
$\mathbf{X}$ Condition of trails/boardwalks

- Safety of Refuge entrances

口Disabled access

Figure 12. Importance-satisfaction ratings of transportation-related features at refuges. 


\section{Visitor Opinions about National Wildlife Refuge System Topics}

One goal of this national visitor survey was to identify visitor trends across the Refuge System to more effectively manage refuges and provide visitor services. Two important issues to the Refuge System are transportation on refuges and communicating with visitors about climate change. Basic results for all participating refuges are reported here.

\section{Alternative Transportation and the National Wildlife Refuge System}

Visitors use a variety of transportation means to access and enjoy national wildlife refuges. While many visitors arrive at a refuge in a private vehicle, alternatives such as buses, trams, watercraft, and bicycles are increasingly becoming a part of the visitor experience. Previous research has identified a growing need for transportation alternatives within the Refuge System (Krechmer and others, 2001); however, less is known about how visitors perceive and use these new transportation options. An understanding of visitors' likelihood of using certain alternative transportation options can help in future planning efforts. Visitors were asked about alternative transportation options at national wildlife refuges in the future.

Of the six Refuge System-wide alternative transportation options listed on the survey, the majority of visitors were likely to use the following options at national wildlife refuges in the future (fig. 13):

- an offsite parking lot that provides trail access for walking/hiking onto the refuge;

- a boat that goes to different points on refuge waterways; and

- a bus/tram that runs during a special event.

The majority of visitors were not likely to use a bus/tram that takes passengers to different points on refuges (such as the visitor center) or a bike share program on refuges in the future (fig. 13).

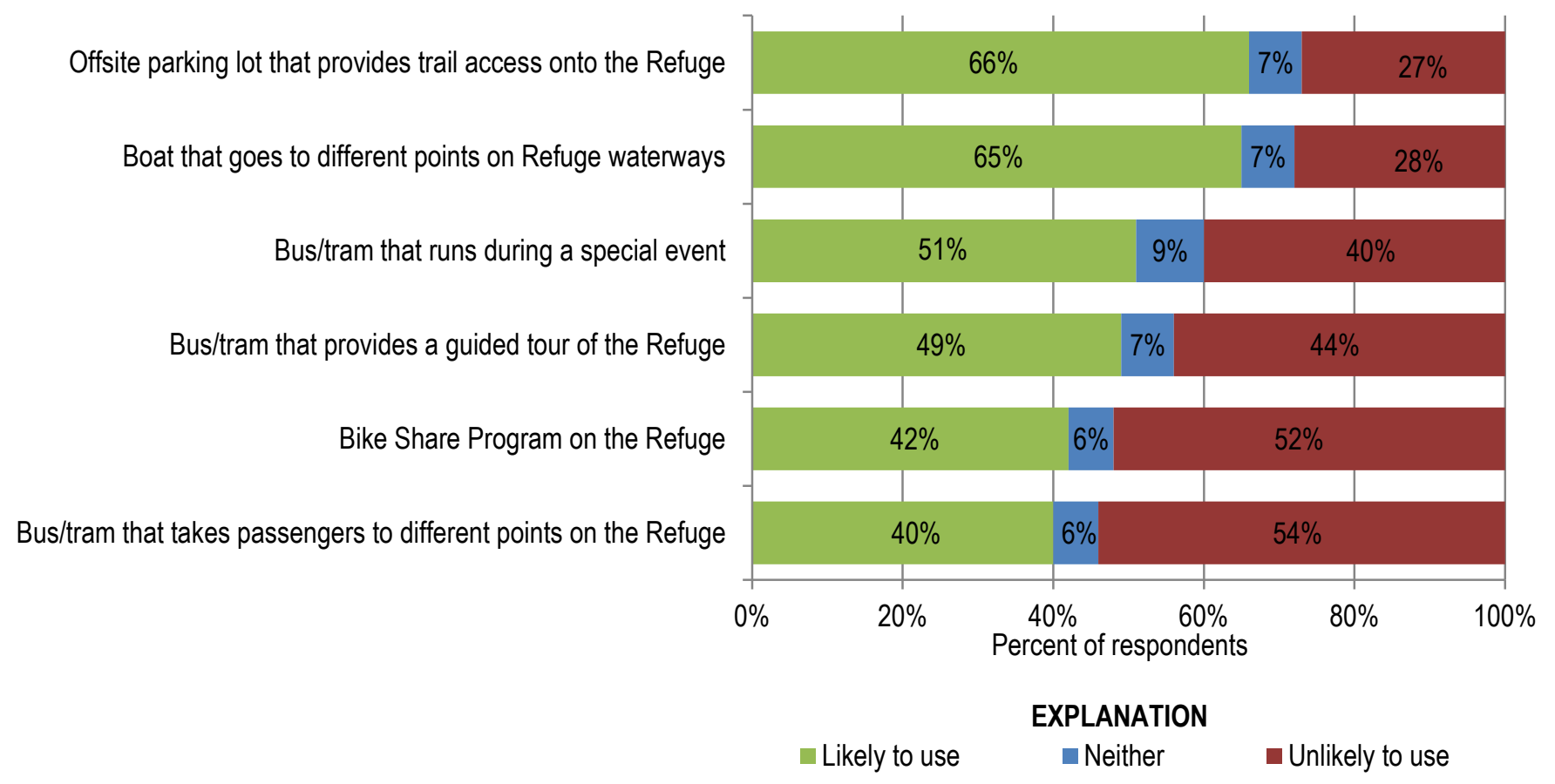

Figure 13. Visitors' likelihood of using alternative transportation options at refuges in the future $(n \geq 9,770)$. 


\section{Climate Change and the National Wildlife Refuge System}

Climate change represents a growing concern for the management of National Wildlife Refuges. The Service's climate change strategy, titled "Rising to the Urgent Challenge," establishes a basic framework for the agency to work within a larger conservation community to help ensure wildlife, plant, and habitat sustainability (U.S. Fish and Wildlife Service, 2010). To support the guiding principles of this strategy, refuges are exploring options for more effective engagement with visitors on this topic. The national visitor survey collected information about visitors' level of personal involvement in climate change related to fish, wildlife and their habitats and visitors' beliefs regarding this topic. Items draw from the "Six Americas" framework for understanding public sentiment toward climate change (Leiserowitz, Maibach, and RoserRenouf, 2008) and from literature on climate change message frames (for example, Nisbet, 2009). Such information provides a baseline for understanding visitor perceptions of climate change in the context of fish and wildlife conservation that can further inform related communication and outreach strategies.

Factors that influence how individuals think about climate change include their basic beliefs, levels of involvement, policy preferences, and behaviors related to this topic. Results presented below provide baseline information on visitors' levels of involvement with the topic of climate change related to fish, wildlife and their habitats. The majority of visitors agreed with the following statements (fig. 14):

- "I am personally concerned about the effects of climate change;"

- "I stay well-informed about the effects of climate change;" and

- "I take actions to alleviate the effects of climate change."

I am personally concerned about the effects of climate change on fish, wildlife and habitats

I stay well-informed about the effects of climate change on fish, wildlife and habitats

I take actions to alleviate the effects of climate change on fish, wildlife and habitats

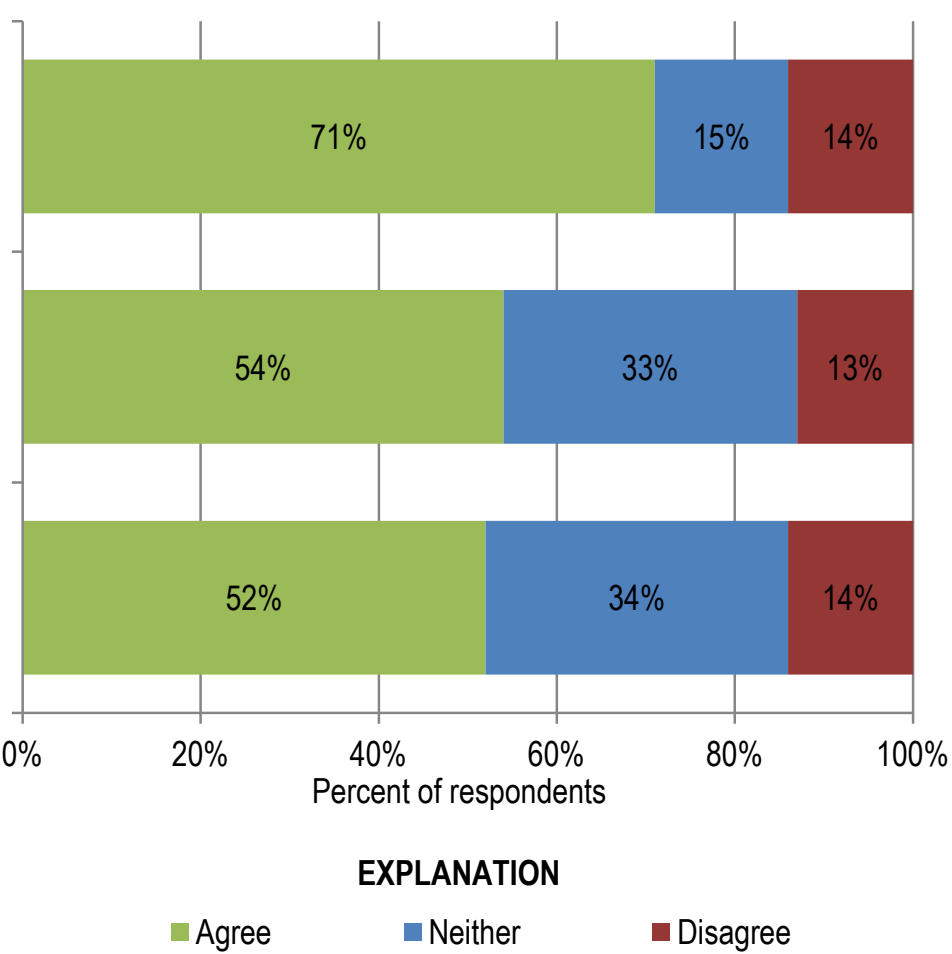

Agree $\quad$ Neither $\quad$ Disagree

Figure 14. Visitors' personal involvement with climate change related to fish, wildlife and their habitats $(n \geq 9,596)$. 
These results are most useful when coupled with responses to belief statements about the effects of climate change on fish, wildlife and their habitats, because such beliefs may be used to develop message frames (or ways to communicate) about climate change with a broad coalition of visitors. Framing sciencebased findings will not alter the overall message, but places the issue in a context in which different audience groupings can relate. The need to mitigate impacts of climate change on refuges could be framed as a quality of life issue (for example, preserving the ability to enjoy fish, wildlife, and their habitat) or an economic issue (for example, maintaining tourist revenues, supporting economic growth through new jobs/technology).

The majority of visitors believed the following regarding climate change related to fish, wildlife and their habitats (fig. 15):

- "Future generations will benefit if we address climate change effects;"

- "It is important to consider the economic costs and benefits to local communities when addressing climate change effects;" and

- "We can improve our quality of life if we address the effects of climate change."

The majority of visitors did not believe "There has been too much emphasis on the catastrophic effects of climate change."

Such information suggests that certain beliefs resonate with a greater number of visitors than other beliefs do. This information is important to note because nearly half of visitors $(46 \%)$ indicated that their experience would be enhanced if refuges provided information about how visitors could help address the effects of climate change on fish, wildlife, and their habitats. Framing the information in a way that resonates most with visitors may result in a more engaged public who support strategies aimed at alleviating climate change pressures.

Future generations will benefit if we address climate change effects on fish, wildlife and habitats

It is important to consider the economic costs and benefits to local communities when addressing climate change effects on fish, wildlife and habitats

We can improve our quality of life if we address the effects of climate change on fish, wildlife and habitats

There is too much scientific uncertainty to adequately understand climate change effects on fish, wildlife and habitats

There has been too much emphasis on the catastrophic effects of climate change on fish, wildlife and habitats

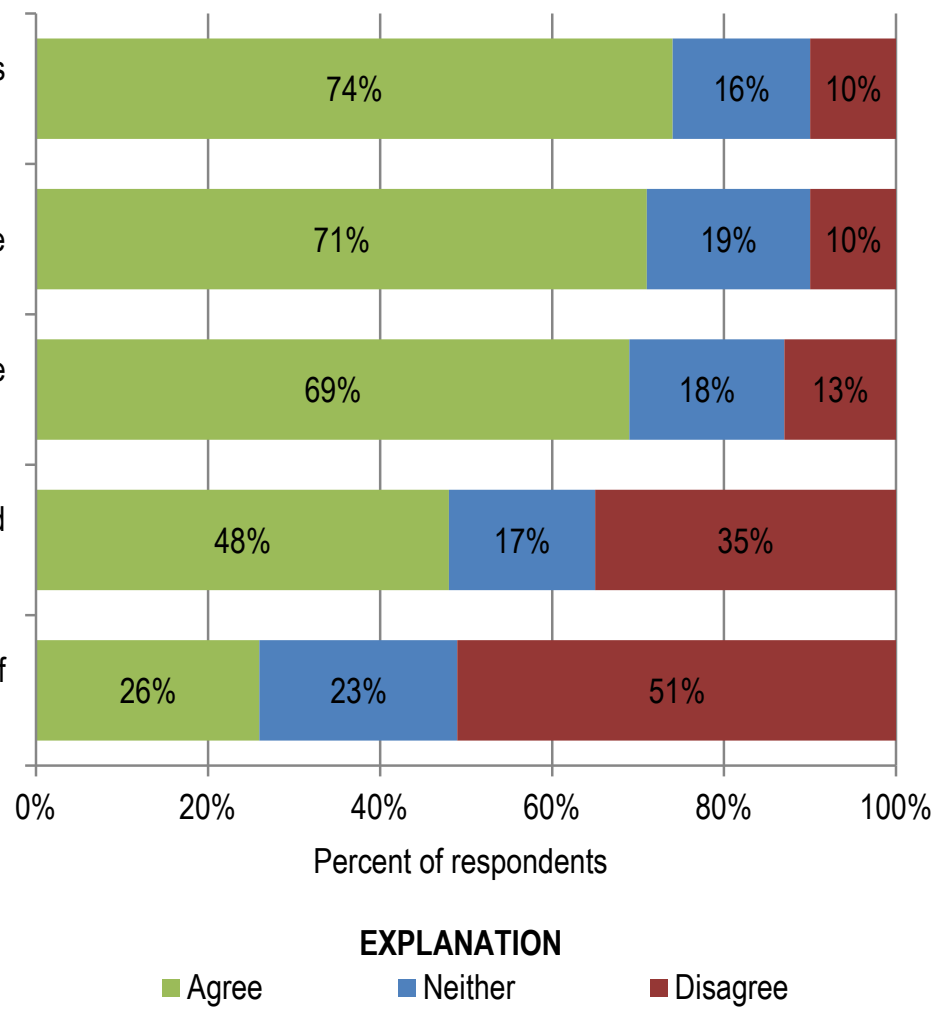

Figure 15. Visitors' beliefs about the effects of climate change on fish, wildlife and their habitats $(n \geq 9,577)$. 


\section{Visitor Spending in Local Communities}

Tourists usually buy a wide range of goods and services while visiting an area. Major expenditure categories include lodging, food, supplies, and gasoline. Spending associated with refuge visitation can generate considerable economic benefits for the local communities near a refuge. For example, more than 34.8 million visits were made to national wildlife refuges in fiscal year 2006; these visits generated \$1.7 billion in sales, almost 27,000 jobs, and \$542.8 million in employment income in regional economies (Carver and Caudill, 2007).

Surveyed visitors were asked to "record the amount that you and other members of your group with whom you shared expenses (for example, other family members, traveling companions) spent in the local 50mile area during your most recent visit to this Refuge." This detailed spending information can be used to construct refuge-level visitor spending profiles for the visitor activities captured during the two sampling timeframes at each refuge. Once constructed, the visitor expenditure profiles can be used to estimate the economic importance of refuge-visitor activities to local communities or to analyze the economic impact of proposed refuge-management alternatives. Construction of the detailed visitor spending profiles is beyond the scope of the survey summary statistics presented in this report. These profiles will be completed as part of follow-up studies.

\section{Conclusion}

These results provide a summary of trip characteristics and experiences of refuge visitors based on a surveying effort conducted on 53 national wildlife refuges during 2010-2011. These data will be used to inform decision-making efforts related to the Refuge System, such as CCPs, field station visitor services evaluations and step-down plans, and transportation planning and management. Specifically, these results can be used to support national-level visitor-services standards on how to welcome and orient visitors, provide quality wildlife-dependent recreation, and evaluate education and interpretation programs. Results will also be used for analyzing long-term facility planning to enhance access to refuges and for the Service's national climate change strategy.

These results are available http://pubs.usgs.gov/ds/685/ as USGS Data Series 685 (Sexton and others, 2012); the 53 individual refuge results are available at http://pubs.usgs.gov/ds/643/ as USGS Data Series 643 (Sexton and others, 2011). For additional information about this project, contact the USGS researchers at national_visitor_survey@usgs.govor 970.226.9205.

\section{References}

Babbie, E.R., 2010. The practice of social research, Belmont, C.A. Wadsworth Cengage, 530 p.

Bruyere, B.L., Rodriguez, D.A., and Vaske, J.J., 2002, Enhancing importance-performance analysis through segmentation: Journal of Travel and Tourism Marketing, v. 12, no. 1, p. 81-95.

Carver, E., and Caudill, J., 2007, Banking on nature 2006: The economic benefits to local communities of National Wildlife Refuge visitation: U.S. Fish and Wildlife Service, Division of Economics, Washington, D.C., 372 p., accessed September 30, 2011, at http://www.fws.gov/refuges/about/ msWord/BankingonNature_2006_11-23.doc.

Clark, J.R., 2001, Mission and Goals (National Fish and Wildlife Service Director's Order \#132-601 FW1), accessed November 18, 2011 at http://www.fws.gov/refuges/policiesandbudget/

HR1420_missionGoals.html.

Dillman, D.A., 2007, Mail and Internet surveys: The tailored design method. (2nd ed.): Hoboken, N.J., John Wiley and Sons, Inc., 523 p. 
Krechmer, D., Grimm, L., Hodge, D., Mendes, D., and Goetzke, F., 2001, Federal lands alternative transportation systems study - Volume 3 - Summary of national ATS needs: prepared for Federal Highway Administration, and Federal Transit Administration in association with National Park Service, Bureau of Land Management, and U.S. Fish and Wildlife Service, 80 p. (Also available at http://www.fta.dot.gov/documents/3039_study.pdf.)

Leiserowitz, A, Maibach, E., and Roser-Renouf, C., 2008, Global warming's six Americas: An audience segmentation: New Haven, Conn., Yale University.

Martilla, J.A., and James, J.C., 1977, Importance-performance analysis: Journal of Marketing, v. 41, p. 7779.

Nisbet, M.C., 2009, Communicating climate change: Why frames matter for public engagement: Environment, v. 51, p. 12-23.

Salant, P., and Dillman, D.A., 1994, How to conduct your own study: New York, N.Y., John Wiley and Sons, Inc.

Sexton, N.R., Dietsch, A.M., Don Carlos, A.W., Miller, H.M., Koontz, L., and Solomon, A., 2012, National Wildlife Refuge visitor survey results: 2010/2011: U.S. Geological Data Series 685.

Sexton, N.R., Dietsch, A.M., Don Carlos, A.W., Koontz, L., Solomon, A. and Miller, H.M., 2011, National Wildlife Refuge visitor survey 2010/2011: Individual refuge results: U.S. Geological Survey Data Series 643.

Stynes, D.J., 2008, National Park visitor spending and payroll impacts, 2007: East Lansing, Mich., Michigan State University, Department of Community, Agriculture, Recreation and Resource Studies.

Tarrant, M.A., and Smith, E.K., 2002, The use of a modified importance-performance framework to examine visitor satisfaction with attributes of outdoor recreation settings: Managing Leisure, v. 7, no. 2, p. 69-82.

Uniack, T., 1999, The citizen's wildlife refuge planning handbook: Charting the future of conservation on the National Wildlife Refuge near you: Defenders of Wildlife, Washington, D.C., accessed April 2010 at http://www.defenders.org/resources/publications/programs_and_policy/habitat_conservation/ federal lands/citizen's wildlife refuge planning handbook.pdf.

U.S. Department of the Interior, Fish and Wildlife Service and U.S. Department of Commerce, U.S. Census Bureau, 2007, 2006 National survey of fishing, hunting, and wildlife-associated recreation: U.S. Department of the Interior, Fish and Wildlife Service, Washington, D.C., 168 p.

U.S. Fish and Wildlife Service, 2007, America's national wildlife refuges, Fact Sheet, last updated July 31, 2007.

U.S. Fish and Wildlife Service, 2010, Rising to the urgent challenge: Strategic plan for responding to accelerating climate change: U.S. Fish and Wildlife Service, Division of Refuges, Washington, D.C., 32 p., accessed April 2011 at http://www.fws.gov/home/climatechange/pdf/CCStrategicPlan.pdf.

Vaske, J.J., Beaman, J., Stanley R., and Grenier, M., 1996, Importance-performance and segmentation: Where do we go from here?: in Fesenmaier, D.R., O'Leary, J.T., and Uysal, M., eds., Recent advances in tourism marketing research: New York, The Haworth Press, Inc., p. 225-240.

Wade, D.J. and Eagles, P.F.J., 2003, The use of importance-performance analysis and market segmentation for tourism management in parks and protected areas: An application to Tanzania's National Parks: Journal of Ecotourism, v. 2, no. 3, p. 196-212. 